W mierze jednak, w jakiej ks. D. wypowiada odnośnie do BT sąd tylko negatywny i kończy wyrokiem tylko potępiającym, bez jakiegokolwiek włączenia się w dzieło, bez jednego słowa pozytywnego, bez wyrażenia jakiegokolwiek uczucia radości, że katolicyzm polski otrzymuje bardziej zrozumiałe Słowo Boże, w tej mierze jakby staje tu poza zasadniczym nurtem biblistyki polskiej. Bo BT jest jednym z jej największych i najważniejszych kroków w okresie powojennym. Wprawdzie ten krok był trochę niepewny, ale został dokonany, i po tym pierwszym, chwiejnym, następne będą bez wątpienia pewniejsze. Spodziewamy się tego tym bardziej, że BT jest świadectwem zrywu i ambicji biblistyki polskiej. Jest również świadectwem narodzenia się ducha zespołowej pracy, co otwiera bardzo szerokie perspektywy. BT zawiera więc wszystkie cienie, ale i wszystkie blaski biblistyki polskiej ${ }^{8}$.

Warszawa

KS. JANUSZ FRANKOWSKI

Ks. Adam Kubiś, Kraków

\title{
PRAKTYKA PENITENCJARNA MĘCZENNIKÓW W PIERWOTNYM KOSCIELE
}

Pod koniec II-go i w pierwszej połowie III-ciego wieku, męczennicy pojednywali grzeszników z Kościołem, zwłaszcza tzw. „upadłych" (lapsi), tzn. tych chrześcijan, którzy zapierając się wiary, złożyli ofiarę bogom.

Wiadomą jest rzeczą, że pokuta w Kościele pierwotnym była bardzo ostra. Otóż, aby ją złagodzić, wierni uciekali się, między innymi, do interwencji męczenników. Miało to zwłaszcza miejsce w czasie prześladowan. Wielu chrześcijan, którzy zaparli się wiary, chciało pojednać się z Kościolem za pomocą „tabliczek pokoju” (libelli pacis), wystawianych przez męczenników, nie czekając na sąd biskupa. Zwyczaj ten był prawie powszechny. Spotykamy go w Lionie za św. Ire-

$8 \mathrm{~W}$ artykule tym powstrzymuję się od omówienia nowego osobnego, wydania NT Biblii Tysiąclecia, ponieważ chodziło mi o całą BT. Nadto znaczenie BT polega przede wszystkim na daniu nam ST. Co do drugiego wydania NT należy wyrazić żal, że jest ono, podobnie jak inne dotychczasowe wydania katolickie, wydaniem drogim - 40 zł. To czego nam potrzeba do upowszechniania znajomości Ewangelii i NT oraz do tworzenia szerokiego ruchu biblijnego jest dużo tańsze wydanie, kosztujące kilkanaście złotych: coś w rodzaju NT wydanego przez Brytyjskie i Zagraniczne Towarzystwo Biblijne. 
neusza, w Rzymie podczas pontyfikatu św. Kaliksta, w Cezarei za Orygenesa, w Egipcie za św. Dionizego z Aleksandrii i w Północnej Afryce od Tertuliana do św. Cypriana. Początkowo był on tolerowany. Kiedy jednak męczennicy poczęli nadużywać swoich prerogatyw, a grzesznicy wspaniałomyślnej dobroci męczenników, Kościół przywiódł jednych i drugich środkami dyscyplinarnymi na drogę ortodoksji 1 .

Nie ulega wątpliwości, że mamy tu do czynienia $z$ wielkim przywilejem męczenników. Należy zatem bliżej zbadać jego znaczenie teologiczne. Będzie nam chodzić po prostu o odpowiedź na pytanie, czy męczennicy występowali w roli sędziów, czy adwokatów i czy ich przebaczenie było niezależne, czy też podporządkowane hierarchii. Innymi słowy, trzeba będzie zbadać, czy męczennicy mieli władzę apostolska kluczy, tj. czy im wolno było z prawa wiązać i rozwiązywać (Mt 16,19; 18,18), czy też raczej rola ich ograniczała się do zwykłej prośby na piśmie skierowanej do władzy kościelnej. Odpowiedź na tak postawione zagadnienie jest bardzo skomplikowana, ponieważ teksty patrystyczne, traktujące o nim, są wieloznaczne ${ }^{2}$. Stąd pochodzi olbrzymia rozbieżność pomiędzy autorami. Mimo to jednak da się podzielić wszystkie opinie na dwie grupy: protestanką i katolicką.

Autorzy protestantcy są zgodni właściwie tylko w jednym punkcie: bez wyjątku wszyscy twierdzą, że męczennicy mieli władzę kluczy w odniesieniu do sakramentu pokuty. Ich zdania są jednak zróżni-

1 Szczegółowe dane na ten temat można znaleźć u następujących autorów: J. P. K i r s c h, Die Lehre von der Gemeinschaft der Heiligen im christlichen Altertum. Eine dogmengeschichtliche Studie, Mainz 1900, ss. 7787. - S. Charrier, Le pouvoir pénitentiel des martyrs, w: Révue Augustinienne, 6/10 (1907) 692-700. - H. A chelis, Das Christentum in den ersten drei Jahrhunderten, II, Leipzig 1912, ss. 346-348; 400-401; 440-441. - A. d'A lès, L'êdit, de Calliste. Étude sur les origines de la pénitence chrétienne, Paris 1914, ss. 244-251. - P. Allard, Martyre, W: DAFC, 3 (1926) 363-364. - H. L e cle r c q, Faillis. w: DACL, 5/1 (1922) 1067-1080; Martyr, w: DACL, 10/2 (1932) 2464-2469. - J. Tixeront, Histoire des dogmes dans l'antiquité chrétienne, I, Paris ${ }^{11} 1930$, ss. 363; 364; $371 ; 373 ; 503 ; 504$. - J. Lebreton - J. Z eiller, De la fin du 2-e siècle à la paix constantinniene, Bloud et Gay 1935, ss. 191-192. J. Grotz, Die Entwicklung des Bussstufenwesens in der vornicänischen Kirche, Freiburg i. Br. 1955, ss. 107-108; 110-111; 115-117; 123-132; 216 przyp. 2; 364 przyp. 3. - P. Galti er, De paenitentia. Tractatus dogmatico - historicus, Romae 1956, ss. $134-135 ; 143-144 ; 519-520 ; 542-543$. M. Lods, Confesseurs et martyrs. Successeurs des prophětes dans l'Église des trois premiers siècles, Neuchâtel - Paris 1958, ss. 67-70. - Skróty są podawane za Lexikon für Theologie und Kirche, wyd. 2.

2 Listę najbardziej kompletną tekstów patrystycznych mówiących o uprawnieniach męczenników $\mathrm{w}$ odniesieniu do sakramentu pokuty podają: A cheli s, dz. cyt., ss. 440-441 (Ekskurs 91). - Galti e r, dz. cyt., ss. $134-135$. - Grotz, dz. cyt., ss. 123-132. 
cowane w określeniu tytułu, dzięki któremu ją posiadali, oraz w zapatrywaniach na jej stosunek do hierarchii.

Najpierw różnica poglądów zarysowuje się w sprawie podstaw teologicznych usprawiedliwiających praktykę penitencjarną męczenników. E. L o h me y e r twierdzi, że krew męczenników może obmywać grzechy, jak krew Chrystusa ${ }^{3}$. G. P. Wetter mówi znowu o konsekracji przez śmierć w męczeństwie (Todesweihe des Martyriums) i nowej hierarchii przez nią stworzonej. Na mocy tej sakry męczennicy byli uprawnieni odpuszczać grzechy i pojednywać ,upadłych" z Kościołem ${ }^{4}$. Lecz najczęściej spotyka się pogląd, że stanowili oni stan osób uprzywilejowanych przez Ducha Sw., w miejsce proroków, po zniknięciu profetyzmu w pierwotnym Kościele 5.

Następnie nie ma jedności wśród protestantów w kwestii wzajemnych stosunków między uprawnieniami męczenników i hierarchii do sakramentu pokuty. Różnica, co do tych uprawnień bywa często posuwana do ostateczności, choć pojawiają się czasem i twierdzenia bardziej umiarkowane. K. $\mathrm{H}_{011^{6}} \mathrm{i}^{\mathrm{R}}$. R e itzens tein ${ }^{7}$ twierdzą, że męczennicy mieli całe i wyłączne prawo odpuszczania grzechów. $\mathrm{Z}$ czasem dopiero hierarchia zajęła ich miejsce. Definitywnie stało się to za św. Cypriana ${ }^{8}$. M. L o d s znowu, przypisując męczennikom wła-

L'idée du martyre dans le judaïsme et dans le christianisme primitif, $\mathrm{w}:$ RHPR, 7 (1927) 316.

${ }_{4}$ „Es scheint, als habe die Todesweihe des Martyriums eine neue Hierarchie in der Kirche geschaffen... In Kraft ihrer Weihe massten sich die Märtyrer z. B. die Befugnis an, die Gewalt Christi auszuüben: besonders in den grossen Verfolgungen beanspruchen sie das Recht, Sünden zu vergeben und Abgefallene in die Kirche wiederaufzunehmen", Altchristliche Liturgie: Das christliche Mysterium. Studie zur Geschichte des Abendlandes, Göttingen 1921, s. 140. - Por. O. M i c hel, Prophet und Märtyrer, Gütersloh 1932, s. 28 . - H. F. von $\mathrm{C}$ a m penhausen slusznie odrzuca ten pogląd. Die Idee des Martyriums in der alten Kirche, Göttingen ${ }^{2}$ 1964, s. 61 .

Do tej grupy autorów należą między innymi: K. Holl, Enthusiasmus und Bussgewalt beim griechischen Mönchtum. Eine Studie zu Symeon dem neuen Theologen, Leipzig 1898, s. 229; Die Vorstellung vom Märtyrer und die Märtyrerakte in ihrer geschichtlichen Entwicklung, w: Gesammelte Aufsätze zur Kirchengeschichte, Bd. II: Der Osten, Tübingen 1928, s. 84. - F. Kattenbusch, Der Märtyrertitel, w: ZNW, 4 (1903) 122 przyp. 1. - Achelis, dz. cyt., s. 348. - Wetter, dz. cyt., s. 140. L o d s, dz. cyt., ss. $79-82$.

(5) Enthusiasmus und Bussgewalt beim griechischen Mönchtum, ss. $225-273$.

Historia Monachorum und Historia Lausiaca. Eine Studie zur Geschichte des Mönchtums und der frühchristlichen Begriffe Gnostiker und Pneumatiker, Göttingen 1916, s. 89. - Por. P. Corss e n, Begriff und Wesen des Märtyrers in der alten Kirche, w: Neue Jahrbücher für das klassische Altertum und Pädagogik, 35 (1915) 485.

${ }_{8}^{8}$ M. Ville r uważa, że opinia ta przesadza w interpretacji tekstów, które mówią o interwencji męczenników w sprawach penitencjarnych i zapoznaje beztrosko wszystkie inne, które przyznają wyłącznie biskupom 
dzę kluczy rozgrzeszania, przyznaje z nią równocześnie i biskupom równorzędne uprawnienia w tym względzie ${ }^{9}$.

W przeciwieństwie do tych opinii katolicy utrzymują, że władza rozgrzeszania należała całkowicie do biskupa, który był jej oficjalnym podmiotem i wykonawcą. Potwierdza to bardzo dobrze tradycja ${ }^{10}$. Lecz nie można - ich zdaniem - zaprzeczyć roli pośrednika odgrywanej przy praktykach pokutnych przez męczenników, którą to rolę akceptowała nawet sama hierarchia ${ }^{11}$. Co więcej, te dwa fakty w pelni ze sobą harmonizują.

Rzecz zrozumiała, że istniały i różnego rodzaju nadużycia. Byli grzesznicy, który chcieli się pojednać z Kościołem wyłącznie przez pośrednictwo męczenników i w ten sposób pominąc władzę biskupa, jedynie kompetentną w tym względzie. Lecz to były wyjątki, a wyjątek potwierdza tylko regułę ${ }^{12}$.

Narzuca się w tym miejscu pytanie zasadnicze, a mianowicie, czym były w swej istocie uprawnienia męczenników. Większość autorów katolickich zgadza się, co do tego, że był to jakiś rodzaj rekomandacji, albo opinii korzystnej. W rzeczywistości polegały one na proźbie skierowanej do biskupa, aby w swej decyzji był łaskawy. „Odnośnie praw męczenników $w$ tej sprawie, pisze J. Tixeront, przyznawano im tylko prawo polecania ,upadłych" biskupowi i troskę o ich reintegrację, lecz nie mogli oni stawiać żądań, a tym bardziej samodzielnie działać" 13. To, czy męczennicy mogli zwolnić grzesznika

wladzę rozgrzeszania. Zob. Les martyrs et l'Esprit, w: RSR, 14 (1924) 549 przyp. 3; Martyre et perfection, w: RAM 6 (1925) 14. M. Ville r $\mathrm{K}$. R a h n e r, Aszese und Mystik in der Väterzeit, Freiburg i. Br. 1939, s. 34. 9 Dz. cyt., ss. $67-68$.

${ }^{10} \mathrm{Ch}$ arrier, art. cyt., ss. 692-693. - Leclerq, Martyr, s. 2465. G a lti e r, dz. cyt., ss. $463-468$.

11 Edykt św. Kaliksta nastręcza najwięcej trudności pod tym względem. Według Tertuliana Papież przyznawał w nim męczennikom prawo odpuszczania tych grzechów, które sam uznał za odpuszczalne. Krytycy jednak nie są zgodni co do tego, czy pozwolenie to własną powagą przywracało pokutnikom członkostwo w Kościele, czy też raczej zalecało ich tylko łaskawości biskupa. W'skazówki bibliograficzne odnośnie dyskusji na ten temat podają: P. de L a briolle, La crise montaniste, Paris 1913, ss. 448-449 przyp. 1. - Tixeront, dz. cyt., s. 361 przyp. 1.

$12 \mathrm{Ch}$ arrier, art. cyt., s. 694 . - A $11 \mathrm{ard}$, art. cyt., 363-364. Le c lerc q, Martyr, ss. 465-466. - Vill e r - R a hn er, dz. cyt., s. 34. F.J. Dölge r mówi o tendencji istniejącej w północnej Afryce do udzielania męczennikom specjalnych uprawnień. Christophoros als Ehrentitel für Martyrer und Heilige im christlichen Altertum, w: AuC, 4 (1934) $74-75$.

13 "Quant aux droits des martyrs en cette affaire, on ne leur en reconnaît qu'un, celui de recommander à l'évêque les lapsi et de solliciter leur réintégration, mais sans pouvoir l'exiger ni, à plus forte raison, l'opérer eux-mêmes", dz. cyt., s. 371. - J. Grotz w pelni potwierdza ten pogląd: „,Der Märtyrer verhilft zur communio, der Bischof vergibt”, dz. cyt., s. 127. 
z regularnej, przysługującej mu pokuty, jak tego chciał J. B a ti ff o 1 , pozostaje wątpliwe $\mathbf{1 4}$.

Należy jednak podkreślić, że ta rekomendacja miała wielkie znaczenie dla ,upadłych”, ponieważ wstawiennictwo męczenników na ziemi było uważane za równie skuteczne jak u Pana Boga. J. P. $\mathrm{Kirsch}$ zauważa, że w oczach wiernych zasługi męczenników miały wartość zadośćczyniącą. Mogli oni swoją prośbą ubłagać zmiłowanie Boga dla innych chrześcijan. To nadawało szczególnego znaczenia ich prośbie 15. Ponadto, męczennicy antycypowali w stosunku do grzeszników swą rolę adwokatów, która przysługiwać im miała na sądzie ostatecznym. Jako zwycięzcy szatana mieli oni możność otworzyć „upadłym” drogę zwycięstwa ${ }^{16}$. Nic więc dziwnego, że te wszystkie przeobfite łaski wywierały wpływ na hierarchię i spływały na grzeszników. W konsekwencji interwencja męczenników zyskiwała renegatom pojednanie $\mathrm{z}$ Kościołem u kompetentnej władzy w minimum czasu. Bez niej byliby oni zmuszeni poddać się długiej i surowej pokucie 17 .

Lecz władza pokutna męczenników nie zastępowała ani nie uzupeiniała władzy rozgrzeszenia posiadanej przez biskupów. Pojednanie otrzymane za pośrednictwem męczenniḱw uzyskiwało swój pełny skutek dopiero po jego ratyfikacji przez władzę biskupią ${ }^{18}$. Z tego właśnie powodu praktyka ,tabliczek”, poświadczona i zatwierdzona przez św. Cypriana, broniła równocześnie praw hierarchii ${ }^{19}$, a synod kartagiński z 251 r. mógł znieść przywileje męczenników w odniesieniu do sakramentu pokuty. Jego decyzje nie respektują w ogóle „tabliczek pokoju” wystawianych przez męczenników i przypadek każdego z „upadłych" miał być z osobna zbadany. Chociaż męczennicy nie są tam imiennie wymienieni, to jednak ich prerogatywy zostały zniesione. Jeszcze ważniejsze jest to, że synod afrykański przyjął tutaj postawę Kościoła rzymskiego 20.

W konkluzji zwrócimy jeszcze uwage na dwie sprawy.

$1^{\circ}$ Praktyka penitencjarna męczenników w tych granicach, które jej zostały zakreślone, stanowi dowód na praktykę odpustów w Koś-

14 Études d'histoire et de théologie positive. La discipline de l'arcane. Les origines de la pénitence..., Paris 1920, s. 89.

${ }_{15}$ Dz. cyt., ss, 86-87. - Por. M. S c h m a u s, Katholische Dogmatik, Bd. 4/1: Die Lehre von den Sakramenten, München ${ }^{5}$ 1957, ss. 598; 605.

${ }_{16}$ L o d s, dz. cyt., ss. $68-69$.

17 „Martyres, qui datis libellis pacis, impertiunt lapsis pacem secus non consequendam nisi post longam ac legitimam paenitentiam", Galtier, dz. cyt., s. 519 .

${ }_{18}$ Leclerq, Martyr, s. 2468. - Por. Charrier, art. cyt., s. 699. A 11 a rd, art. cyt., ss. $363-364$. - G a lti e r, dz. cyt., ss. 133-149.

19 Galtie r, dz. cyt., s. 184.

20 Charrier, art. cyt., 699. - Tixeront, dz. cyt., s. 373. 
ciele pierwotnym. Wiadomo bowiem, że praktyka odpustów opiera się na przekonaniu, iż wierni mogą przenosić własne zasługi na pożytek duchowy innych, żywych lub zmarłych, jeżeli nie są potępieni, i w ten sposób uwolnić ich od kary doczesnej należnej za grzechy. Męczennicy polecali grzeszników właśnie w imię tego przekonania. Innymi słowy, była to antycypacja praktyki odpustów ${ }^{21}$.

$2^{\circ}$ Praktyka penitencjarna męczenników świadczy o wielkim względem nich uznaniu Kościoła. Stąd jest ona niewątpliwie jakąś formą kultu, którym ich otaczano w Kościele pierwotnym ${ }^{22}$.

Kraków

KS. ADAM KUBIŚ

Ks. Józel Krasiński, Sandomierz

\section{SPOLECZNY CHARAKTER MSZY SWW. WEDLUG "INSTITUTIO GENERALIS MISSALIS ROMANI"}

Nowe Ordo Missae zaaprobowane przez papieża Pawła VI konstytucją apostolską „Missale Romanum” (3 kwietnia 1969 r.) zostało ogłoszone przez Sw. Kongregację dla Kultu Bożego dnia 6 kwietnia 1969 r. Zakończyła się epoka dobrze już wysłużonego (jak to podkreśla Paweł VI w konstytucji) Mszału Trydenckiego. Zaczęła się epoka Mszału Watykańskiego. Nowe „Rubryki” mszalne, które będą tutaj przedmiotem naszych rozważan zatytułowane są następująco: Institutio Generalis Missalis Romani. Już pierwsza pobieżna lektura wskazuje, że rubrykami można ten dokument nazwać tylko w cudzysłowie. Podkreślają to jednogłośnie wszyscy komentatorowie. Ich zdaniem dokument ten zrywa $\mathrm{z}$ dawną mentalnością rubrycystyczną i kazuistyką moralną, a stanowi piękny traktat teologiczny, pastoralny, ascetyczny, nie tracąc koniecznego dla siebie w pewnej mierze charakteru rubrycystycznego i jurydycznego 1.

Dokument opiera się na pełnej teologii Vaticanum II, wykorzystuje przede wszystkim Konstytucję o Liturgii św., Konst. dogma-

21 Ga 1 ti e r, dz. cyt., ss. $518-520 ; 542-543$.

22 Kirsch, dz. cyt., s. 87.

1 Nocent Adrien $\mathrm{w}$ art. Presentazione del nuovo Ordinario della Messa podkreśla, że fundamentalna cecha nowego Ordo polega bez wątpienia na ,assenza di qualsiasi mentalità rubricistica e moralistica, che caratterizzava il Messale Romano", Rivista di Pastorale Liturgica 1969 (7), S. 448. J. L e c u y e r pisząc o The New Ordo Missae zaznacza, iż „Its style is of course pastoral rather than iuridical and rubrical" i że jest to ,document with a clear, linear structure, inspired by pastoral principles", The American Ecclesiastical Review, 1969 (vol. 161, nr 1), s. 53-54. Por. także O'C onnel J. B., The General Instruction of the Roman Missal, The Clergy 